\title{
Entrevista com Sidney Possuelo, Revista das Aguas, Núcleo de Estudos Amazônicos, 1999
}

Apresentação por Kelerson Semerene Costa ${ }^{1}$

Nesta seção, a Revista Brasileira de Linguística Antropológica publica entrevista realizada com o sertanista Sidney Possuelo, em 1999. Possuelo era, então, chefe do Departamento de Índios Isolados - origem da atual Coordenação Geral de Índios Isolados e de Recente Contato - da Fundação Nacional do Índio e foi sabatinado por nove entrevistadores, incluindo antropólogos, historiadores, indigenistas e jornalistas vinculados à Universidade de Brasília, ao Ministério Público e ao Instituto Socioambiental.

Passados 18 anos, a entrevista conserva importância e merece lugar nesta edição dedicada ao trabalho dos sertanistas por registrar as principais ações e o estado da discussão poucos anos depois que a Funai implementasse nova conduta - da qual Possuelo foi um dos principais idealizadores - para os assim chamados "índios isolados", a evitar a "atração" e o "contato" que marcaram o período anterior.

Naquele momento, os anos finais do século XX, era menor a quantidade de referências sobre índios isolados conhecidas pela Funai, as condutas implementadas com a criação do Departamento de Índios Isolados eram pouco conhecidas e já motivavam fortes polêmicas, e o tema ainda não havia alcançado a repercussão, inclusive internacional, que recebe nos dias de hoje. Por isso, vale a pena voltar a esse registro, com seus debates e polêmicas, mas também com "causos" saborosos - como em toda boa prosa sertanista.

A entrevista, que aqui se reproduz em fac-símile, foi realizada em fevereiro de 1999 e publicada no mesmo ano, no número de lançamento do periódico Terra das águas - revista de estudos amazônicos, breve iniciativa editorial do Núcleo de Estudos Amazônicos da Universidade de Brasília, interrompida no ano seguinte.

\footnotetext{
${ }^{1}$ Professor do Departamento de História e do Núcleo de Estudos Amazônicos Universidade de Brasília.
} 


\section{Entrevista:}

\section{Sydney Possuelo}

Quase 500 anos depois do encontro de Cabral com os antigos habitantes do litoral do que hoje é o Brasil, ainda habitam essas terras povos que a sociedade brasileira não conhece. Depois do extermínio de milhões e, nas últimas décadas, do intenso esforço de atração e contato que acompanhou as frentes pioneiras que marchavam sobre $o$ Centro-Oeste e sobre a Amazônia, ainda existem etnias que não mantêm qualquer contato com nossa sociedade. São os assim chamados indios isolados. As referências a seu respeito são numerosas e continuam surgindo com freqüência,

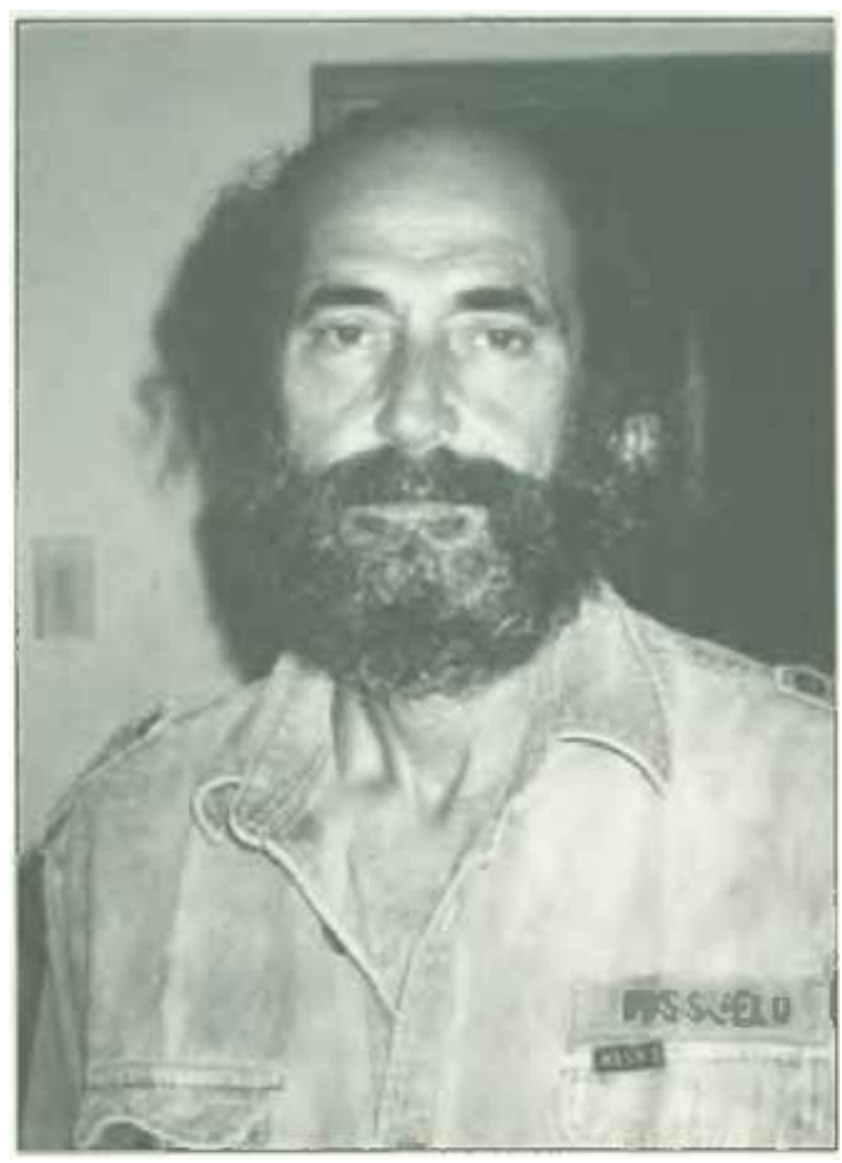
tornando ainda mais complexo o problema das relações interétnicas no Brasil. Ex-presidente da Funai, atual chefe de seu Departamento de indios Isolados, é o sertanista Sydney Possuelo quem coordena o trabalho das equipes que, em diversas frentes, esforçam-se para evitar que se repitam as histórias trágicas de contato entre índios e não-índios. Formado na escola dos irmãos Villas-Boas e com mais de trinta anos dedicados ao sertanismo, Possuelo foi agraciado em 1997 com o Prêmio Bartolomé de Las Casas, do governo da Espanha, que distingue os defensores dos direitos e dos valores dos povos indígenas da América.

Ainda recuperando-se de um grave acidente automobilístico e amparado por muletas - o homem que vive na floresta quase perdeu a vida no deserto do 
Saara - ele gentilmente atendeu ao convite do Núcleo de Estudos Amazônicos $e$, durante quase três horas de uma tarde de fevereiro, na mesa composta por indigenistas, antropólogos, historiadores e jornalistas, ${ }^{2}$ falou sobre seu trabalho com os índios isolados.

A seguir, trechos dessa conversa.



Memélia: Quantos grupos isolados há no Brasil, hoje?

Possuelo: Vinte e dois ou vinte e três... bom, aí estamos incluindo os que conhecemos hoje, aqueles com os quais estamos trabalhado, que já vai dar em torno de uns dez. E uns 12 ou 13 que a gente precisa chegar lá para confirmar, para saber deles. Se ainda estão vivos.

Memélia: E isso dá uma população de quantos, Sydney?

Possuelo: Memélia, a população é tão variada... ela é tão terrível na sua... que é um negócio dramático. Muitas vezes você tem informação de um grupo, como nós tivemos aqui no Centro-Oeste, informações de grupos. Quando você chega lá não é um grupo. E, vai começar a investigar, você vê que são dois ou três índios. Nós tivemos isso no Pará, tivemos em Rondônia agora recentemente, com aqueles dois ou três pequenos grupos ali. Então, quer dizer, essa estimativa é terrível, ela varia de 1 a 150, 200. Então, realmente não dá para estimar. Eu prefiro não falar, vamos falar da importância mesmo sendo um, do que estimar e falar um número que pode ser tão variável, que eu posso quebrar ainda mais a cara do que j á está quebrada [rindo] e com erros muito grandes.

Santilli: Tem um caso radical com o Marcelo. ${ }^{3}$ Como é que faz para identificar uma área para um cara? O cara mora em um buraco, ele cava um buraco do lado da casa dele e fica lá dentro do buraco!

Possuelo: E a nossa equipe em volta! Nós fizemos um filme com ele lá. Aparece ele assim, dentro do buraco, pega ele de lado, parece um tupi, assim perfeito. Ali, um homem sozinho! Eu acho... me desculpe o Marcelo, não concordo, eu acho que não tem que identificar um área para um homem sozinho, eu acho que

${ }^{2}$ Márcio Santilli, ex-presidente da Funai e membro do Instituto Socioambiental ISA; Marco Paulo Schettino, antropólogo da Procuradoria Geral da República; Edward Mantoanelli Luz, do Grupo de Estudos sobre Relação Interétnicas - GERI do Depto. de Antropologia da UnB; Victor Leonardi, Maurício Wilke, Elias Bigio, Memélia Moreira e Kelerson Semerene, do NEAz; e Stephen Grant Baines, do GERI e do NEAz.

${ }^{3}$ Marcelo Santos, indigenista responsável pela unidade de índios isolados em Rondônia. As notas da entrevista são do editor. 
não é por aí. Se é um grupo, um grupo familiar pelo menos... uma mulher, filho, não-sei-que, que tem o mínimo de perspectiva, como os Avá-Canoeiro, que são cinco ou seis aqui em Goiás. Mas não é um homem sozinho. Esse homem sozinho não dá nem para você soltar, fechar uma área e soltar ele porque ele vai desaparecer. Se ele morrer você nem sabe, fica com a área ali, como área indígena, o cara já morreu há muito tempo, você não tem como acompanhar nem nada, né? Eu acho que a solução seria outra. Por exemplo, inicialmente, o que você poderia fazer, como ele está ali, naquela região, é simplesmente interditar a área. Isso a Funai podia fazer: interditar um espaço razoável ali para aquele homem, para a nossa equipe tentar se aproximar dele etc. Para mais tarde você ver o que vai fazer. Escutando ele um pouco, até ver com certeza...

Edward: Já sabem qual é a língua dele?

Possuelo: Não! Ele não deixa ninguém se aproximar! Nosso pessoal se aproximou dele, ele puxou do arco e jogou flecha no pessoal.

Memélia: Onde é isso?

Possuelo: Isso é lá em Corumbiara. ${ }^{4}$

Elias: Houve uma interdição e parece que agora tinha expirado o prazo.

Possuelo: É, houve a interdição. Ali a coisa é um pouco mais complicada, porque isso não é tão isolado dos demais acontecimentos. Nessa mesma região, próximo, foi feito um contato com quatro índios, inicialmente. Depois, esses quatro se transformaram em onze. Apareceram mais sete índios de uma outra etnia. E todos, embora inimigos entre si, tiveram de viver juntos. Até que aconteceu uma morte, um grupo matou a mulher do outro grupo menor, de quatro - isso já faz uns dois anos. Quando nós pensávamos que eram onze índios - agora dez por causa da mulher que havia sido morta - apareceu mais esse outro. Isso faz parte, isso é o resultado desse processo terrível que fizeram em Rondônia, que estão fazendo no Pará, com essa devastação, essas estradas, essas vicinais. Entende? Um flagelo decorrente desse tipo de coisa. Quando não mata todos, quer dizer, desaparecem, sobram esses dramas que você encontra mais tarde. Sete aqui, oito ali, dez, doze, um. Como aquele que eu peguei aqui no Centro-Oeste..., na Bahia, entende?

Santilli: Um Avá né?

Victor: Como foi? Pode nos contar um pouco como foi isso?

Possuelo: Avá não, ele era Awá-Guajá. Esse que eu encontrei aqui foi o seguinte: passou um antropólogo ${ }^{5}$ por lá e escutou falar que num determinado lugar tinham pego uma pessoa, que essa pessoa falava uma língua... Só que quando

\footnotetext{
${ }^{4}$ Estado de Rondônia.

${ }^{5}$ AndreaTonacci.
} 
ele viu, era um índio que estava por aí. Bem, e ele informou isso nos jornais do Rio de Janeiro:

- Tem um índio que uma população encontrou, em tal lugar, assim, assim...

Era isso. E aí eu comecei a estudar para sair atrás. A Funai na oportunidade não me deu as mínimas condições, aliás não me deu nada, não quiseram, $\mathrm{o}$ presidente não quis que eu fosse... e eu peguei o meu carro, eu e o Welington, ${ }^{6}$ e fomos embora.

Aí, quando cheguei lá, procurei, procurei... até que descobri, na serra, no sopé da serra do Divisor - essa grande serra que divide a Bahia com o Tocantins e tudo mais - esse homem. Ele

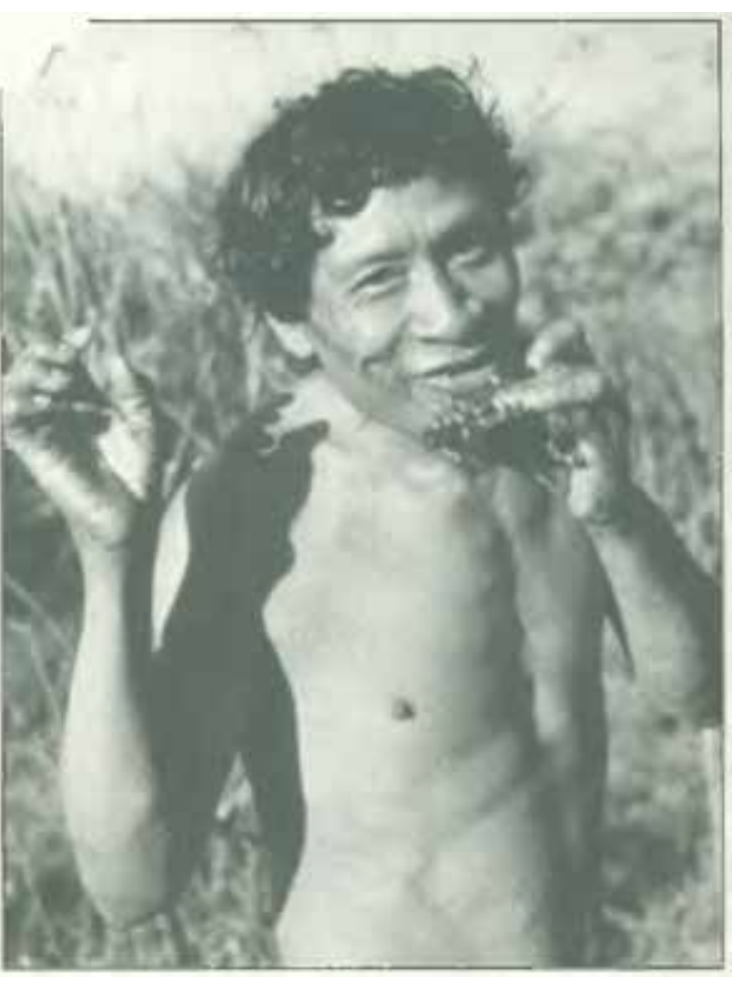

Karapiru, índio awá-guajá do Maranhão, deliciando-se com mel silvestre. Foto: Renato Sanchez veio pela serra e ficou dez anos andando na serra. Até que desceu. Quando desceu, começaram os problemas, e ele não estava só, estava com outro índio. Ele foi atacado, perseguido, porque começou a matar boi para comer. Aquela coisa que os Avá-Canoeiro também faziam. Começaram a persegui-los. Então os dois se separaram. Ele e esse outro rapazoia - quando o encontrei, tinha de 17 para 18 anos, esse outro, que foi um segundo que contatei. Enfim, dois homens sozinhos, sobreviventes de um ataque que aconteceu lá no Maranhão. Lá em cima, a mais de $2.000 \mathrm{~km}$ de distância.

Sobreviveram dez anos lá em cima e vieram. Quando desceram da serra onde não mora ninguém - para comer, começaram a matar porco e tal, e coisas do gênero — o pessoal da região começou:

—Que é isso?

Um dia entrou um porco no meio da corrutela, um porco com uma flecha... foi mal flechado.

—Mas que é isso?

— Um porco! Nossa!

${ }^{6}$ Welington Figueiredo, sertanista da Funai. 
— O que é isso? Uma flecha!

Um porco ganindo no meio do arraial! Juntou todo mundo, começou acercar, foi indo, foi indo... no final, um homem pelado. Ele sorrindo, peladão, com um arco e uma flecha na mão, sorrindo. Pegaram ele e não fizeram nada. Ainda bem que não bateram, não fizeram nada. E eles ficaram lá com ele. E queriam ficar com ele. Isso também é tipicamente regional, né?

- Me dá um indiozinho para eu criar, porque ele vai comprar cigarro para $\operatorname{mim} .$.

Vai ser um serviçal. Se ele ficasse ali, ele iria virar um serviçal. Mas nós fomos lá, resgatamos ele, o trouxemos para Brasília. Depois tive um problema com os lingüistas e com os antropólogos, tivemos problemas sérios, por divergências. Mas, no final, nós vimos que... nós vimos não, eles viram que nós tínhamos razão, que ele era realmente um Awá-Guajá e não um Avá-Canoeiro. Bobagens! Bobagens técnicas.

Então levamos ele de volta para o Maranhão. Ele mora lá até hoje. Três dias atrás eu estava com uma pessoa que veio de lá e eu estava perguntando sobre ele...

\section{Santilli: Ele está no $\operatorname{PINF}^{7}$}

Possuelo: Está lá no Guajá. E está bem! Teve muito problema no início, depois de dez anos sozinho, desconfiado do mundo e tudo mais. Era isolado antes, era um índio isolado, era um grupo isolado. A história foi a seguinte: eles estavam em uma área no Maranhão que era uma fazenda, e foram atacados pelos fazendeiros. Quando foram atacados, o grupo se dispersou, alguns foram mortos. Sobraram ele, a esposa, a filha e um outro menino. O outro filho dele, que era uma criança de uns sete anos, seis... - deve ser isso, cinco para seis anos - ficou preso numa cerca de arame e os fazendeiros pegaram ele.

Mais tarde a Funai soube e pegou esse menino da cerca de arame. Ele foi criado pela Funai. Já tinham se passado dez anos e ele era funcionário da Funai. Ficou criado pela Funai e trabalhava na nossa frente, junto conosco. O pai tinha desaparecido nessa história. O quê que aconteceu? A mãe e a irmã morreram de diarréia. Ficou só o Karapiru, o pai dele, e mais esse outro menino — que era menino na época, quando o encontrei já tinha 16 ou 17 anos, mas tinham se passado dez anos. Então os dois sobreviveram, até que, descendo da serra, começando a vida de rapinagem, matando uma coisinha aqui, outra ali, os brancos deram... e eles se separaram. Ele ficou sozinho naquela região da Bahia e o outro veio até Unaí. ${ }^{8} \mathrm{O}$ outro eu fui encontrar em Unaí. Eu não! Na verdade, nas mesmas circunstâncias, pegaram ele numa fazendola, num lugar daqueles,

\footnotetext{
${ }^{7}$ Posto Indígena.

${ }^{8}$ Município de Minas Gerais, a 170km de Brasília. 
o levaram e - tipicamente nosso - já puseram ele num cárcere. Eu fui tirar ele de dentro de um cárcere da polícia. Estava lá, um índio isolado, pelado, preso. Esse foi o primeiro contato dele, direto, fora os conflitos que ele tinha vivido. Foi um drama terrível tudo o que passaram.

Agora, imagina esse outro sozinho também. A nossa equipe está em volta e não sabe mais o que faz. Não quer pular em cima dele. Eu até falei para o pessoal [rindo]:

- Se der, segura o cara de amarra. Ele tem que saber o que nós queremos.

Então, o pessoal senta em volta, bota comida para ele, ele flecha a panela com a comida... É assim, ele não quer saber, enquanto você fica ali, ele não faz nada. Aí, deixaram uma câmera, dessas pequenas, filmando. Uns dez minutos depois que o pessoal saiu, ele bota a cara assim, aí ele sai do buraco, ainda pega ele saindo.

É assim um caso, deverá haver, eu diria, dezenas de casos como esses homens sozinhos sobrevivendo nessa região de Rondônia, agora pegando o Acre também. O Acre, é uma situação um pouco melhorada, mas tem muita coisa. No Pará também, nós encontramos dois homens, assim, sozinhos! E até hoje falam tupi, não se sabe que tupi, não descobriram direito a língua deles até hoje. Ninguém sabe nada sobre aqueles dois homens que as nossas equipes encontraram também no Pará. Esses são os casos de menor repercussão porque são casos isolados. Repercute mais quando é:

— Encontrou aldeia de não-sei-o-quê... são cem índios, oitenta...

Quando formam grupos maiores, aí as pessoas dão mais atenção. Quando é um homem sozinho desaparece, praticamente, o interesse até da própria Funai... É um indivíduo que sobrou. Aquele negócio do último dos moicanos, é uma verdade, né? Acontece na vida aí, de monte. É isso.

Memélia: Sydney, tu várias vezes tens dito que sertanista, as pessoas que fazem atração, na verdade vão amortecer o choque que vai vir. Um monte de frentes, um monte de indios que já contatastes - e o caso mais grave dos Araras -, tu achas que vale a pena ir lá e mostrar tudo, tu achas que ainda é necessário você fazer isso? Contatar para depois a gente chegar e matar de uma forma ou de outra? Ou com doença, ou com morte matada...

Possuelo: Isso foi uma política da década de 1970. Quando nós criamos o Departamento de índios Isolados, era para mudar essa política. Com a criação do Departamento de índios Isolados, mudou essa política. Nós introduzimos uma nova política dentro do Funai, que pode ser resumida assim: índio isolado, você verifica onde ele está e protege. A função básica do departamento é proteger os índios isolados e não mais fazer contato. $\mathrm{E}$ isso foi um problema, eu tive de fazer muitas reuniões, até fundar o departamento dentro desses princípios, 
porque era muito combatido, ninguém queria esse negócio:

- Não! O que é isso!

Até hoje elas são contraditórias. Outro dia eu estava lendo um cara de Cuiabá dizendo:

- Não, nós vamos sair, fazer um contato com um grupo de índios que tem nãosei-aonde, não-sei-o-que, não-sei-o-que-lá...

Quer dizer, não é departamento dele, não é coisíssima nenhuma dele, é uma área nossa mas ele estava dizendo isso. Faz parte daquele grupo de pessoas que acham que os grupos que ainda existem têm de ser contatados, têm de ser integrados, entende? Isso em função de quê? Dessa coisa nova, a tal globalização, o "destino manifesto" : tem que ser assim porque tem que ser. Os índios isolados não têm nada a ver, os grupos indígenas não têm nada a ver com o que nós arranjamos no mundo inteiro: as nossas questões comerciais, as nossas questões de ocupação de espaço, as nossas sujeiras, eles não têm nada a ver com isso. Querer dizer que tem de fazer contato porque nós precisamos de mais terras, porque nós..., porque o mundo é assim, porque a globalização nos leva, é não olhar o lado dos índios. Quem faz isso não olha o lado dos índios, não vê os índios, vê com outro tipo de interesse. Pode ver o interesse do Estado, da não-governamental, o interesse particular, mas não vê o dos índios. Não vê! Então, para o índio isolado, o negócio é ele se manter isolado. Deixar ele ser feliz nesses dias. Nós somos infelizes, não conseguimos nada na nossa vida!

Memélia: Nessa politica de contato, por que se mantêm frentes de atração em área de... aqueles índios lá do Acre que volta e meia querem matar todo mundo. Por que se mantém uma frente de contato, não só se demarca, delimita e deixa eles à vontade?

Possuelo: Mas a frente não é uma frente de contato. Ela tem esse nome porque todas as frentes chamam "frente de contato" e até hoje não se pôde mudar. São sete as frentes de contato e ninguém está fazendo contato. Está lá! O Meirelles ${ }^{9}$ está lá, há mais de dez anos tem aquela frente. No entanto, ele nunca foi atrás de contato. Não é verdade! As frentes...

Memélia: Mas não atacaram?

Possuelo: Agora! Mas nunca foram! Nós estamos falando agora, de meses passados. O Meirelles está lá há dez ou onze anos. Ali era o seguinte [desenhando um mapa]: cabeceira de rio. Era isso aqui. Aqui já é outro país e aqui se encontraram índios isolados. Daqui, do trecho médio desse rio para baixo era só índio Kaxináua, Jamináua e não-sei-o-quê-mais... Todos já integrados, todos já seringueiros, usam armas, em contato com brancos há decênios. Toda vez,

${ }^{9}$ José Meirelles, sertanista da Funai. 
esses índios subiam daqui, iam lá em cima e matavam os isolados. Desciam. Vinham para Rio Branco, em Rio Branco eles contavam as histórias que saíam nos jornais. Eu tenho um monte de histórias dessas que nós fomos acumulando e guardando, eles contando seus feitos heróicos, de matar outros índios brabos. Então, nós colocamos exatamente uma equipe no meio que fazia o seguinte trabalho - isso continua sendo o trabalho do Meirelles até hoje, lá em cima: evitar que esse grupo aqui vá além da frente do Meirelles para não se encontrar com o grupo lá de cima. O grupo lá de cima começou a ver, descobriu o Meirelles aqui em baixo e fez uns três ataques em cima do Meirelles. Nós tivemos dois homens feridos lá em cima, em três ataques. Até que eles deduziram:

— Tudo bem. O pessoal não faz nada...

Então, acabou. Durante esses últimos dez anos acabou aquele negócio de índio já com coisas de brancos, com a parafernália, com as armas de branco, subir lá em cima e matar os outros. Acabou.

Agora, uma equipe estava fazendo a demarcação da área. O Meirelles deixou o acampamento para dar suporte para essa equipe, para andar com eles no meio do mato. Eles estavam andando, fazendo uma linha, e quando iam iniciar essa linha foram cercados por índios isolados. Quando soube, peguei um helicóptero e fui lá. Tiramos o pessoal. Eu falei:

- Pára com essa demarcação e vamos tirar esse pessoal nosso. Em vez de eles virem por terra, cora o risco de confronto, vamos resgatá-los de helicóptero.

No momento da retirada, um outro grupo de índios - agora nós não sabemos que grupo é - foi no acampamento do Meirelles, atacou e meteu fogo em tudo. Perdemos os equipamentos, perdemos tudo, todas as coisas. Estávamos começando, na tentativa de reconstruir aquilo tudo, quando acabou o dinheiro, acabou tudo, o Meirelles teve de baixar, teve de sair, e não há dinheiro para absolutamente mais nada.

Santilli: Onde é isso, exatamente?

Maurício: É no Envira. ${ }^{10}$

Possuelo: Enfim, então essa é a situação. Mas voltando à sua resposta, Memélia, há muito tempo que nós não queremos fazer o contato, entende? Há muito tempo! Desde que se criou o Departamento, isso está em sua normas. O contato... não é que nós não faremos mais o contato. Não. Um homem desse sozinho, o quê que você vai fazer com ele? Vai ter que contatar. Você encontra dois ou três índios sozinhos numa selva daquelas, entre o capão de mata de uma fazenda com outra fazenda, você tem de resgatar essas pessoas. Não tem outra forma. Agora, por que fazer contato, por exemplo, com essa aldeia que nós

${ }^{10}$ Rio Envira, estado do Acre. 
vimos lá? Meirelles estava comigo no sobrevôo. Nós vimos, contamos mais de 15 ou 16 casas imensas. Imensas as casas! Por que fazer contato com os Korubo lá em cima? Não tem necessidade de fazer o contato.

Santilli: É, mas não sei. Concordo com você, e você sabe disso. Mas vou problematizar essa questão. Existem, entre esses casos que são conhecidos, alguns em que os índios são isolados porque a gente dá esse nome, porque na verdade eles estão em contato com fazendeiros, com regionais. Esses de Rondônia, por exemplo.

Possuelo: De Rondônia! Mas isso não é contato, amigo. Há uma diferença fundamental entre você estar contatado... que o índio que tem contato com qualquer fazendeiro, você não precisa de uma equipe para ir lá fazer o contato com ele, você entra na aldeia, entra e sai e não é problema. Você vai me dizer que esse homem sozinho, que está lá, com arco e flecha, dentro do buraquinho dele, ele tem contato regular com fazendeiro? A nossa equipe está lá e não consegue fazer o contato - e são homens com uma vivência grande, razoável — você vai me dizer que esse homem tem contato regular com fazendeiros?

Santilli: Não estou dizendo que esse cara tem, entendeu? Estou dizendo que, em muitos casos, os grupos têm contato ou com missionários ou com narcotraficantes eu sei lá com quem. O problema...

Possuelo: Eu não entendo qual é o problema. O problema é o nome de índios isolados?

Santilli: Não! O problema é saber o quê você faz. Porque na verdade ele é isolado no sentido de que o Estado brasileiro não oficializou uma relação de contato. Mas ele está lá, em contato com a sociedade regional.

Possuelo: Não é verdade! Não é verdade! Não é verdade!

Santilli: Eu discordo de você!

Possuelo: Ele não está em contato com a sociedade. Essas aldeias que estão lá, que nós descobrimos - a não ser que você chame isso de contato - as únicas informações de que dispomos foram, nesses últimos anos, das mortes que provocaram aos brasileiros que estão lá. As de que eles morreram, que os índios foram mortos, ninguém sabe, porque aí ninguém fala nada. É isso que você chama contato? Se é isso, então eles são contatados, amigo. Se você chama isso de contato, eles já estão contatados. Não é verdade! Quem diz isso — perdoa, com todo o respeito a você — desconhece o que seja a situação, em realidade, de vivência, de estar e de conhecer. Não é verdade!

Memélia: Vamos completar o que o Márcio disse. No caso dos Arara, que a gente acompanhou bem de perto, eles viviam em contato - e isso está no teu relatório de 1982, de 1980 aliás —, que mantinham contatos esporádicos, 
acho, que tu dissestes no teu relatório, com os gateiros, com aquele pessoal que andava por ali, pescador e tudo mais. É um tipo de contato. Pode não ser um contato oficial, um contato como o Márcio diz, um contato do Estado, mas é um contato. É de conflito? É de conflito, mas não deixa de ser um contato. E o contato com o Estado não é menos conflitante. Ou você pensa que a Cotrijui, ${ }^{11}$ que ocupou a terra dos Arara, ali, e foi a partir do Estado, é um contato de menos conflito do que o que eles tinham com os gateiros? Eu não vejo diferença entre você ser morto pelo Estado e ser morto por um gateiro. Realmente! Acho que isso é um tipo de contato, não é aquele contato tradicional: bota panelinha, devolve mel, bota não sei o que, tá, tá, tá...

Possuelo: Primeiro, não é em um relatório meu sobre os Arara que você vai encontrar isso, não. Você vai encontrar a palavra "confrontos". Você vai encontrar nos meus relatórios: "eles tiveram con-fron-tos".

Meraélia: Eles trocavam coisas com os gateiros.

Possuelo: Mas confronto não é contato. Confronto é o ato de eles estarem ali e serem agredidos e eles correm e tocam flechadas e isso e aquilo...

Santilli: Mas eu não estou querendo confrontar a posição que você colocou. Eu estou querendo tirar de você essa coisa radical, que é...

Possuelo: De quê?

Santilli: Que é ... qual é o momento em que você tem de fazer a violência, optar entre uma forma de violência, entendeu? Tem uma hora que você tem de dizer: - Porra, eu tenho que ir lá, eu tenho que fazer o contato com esse cara, senão ele morre. Certo?

Possuelo: Existe algum momento em que nós temos de ir lá?

Santilli: Você deve ter tido momentos, em sua vida, não sei como é isso...

Possuelo: Me diz uma coisa, por que que essa aldeia que nós vimos agora com 15 ou 16 malocas - , porque depois de demarcada, você mesmo falou agora, Memélia, por que depois de demarcada não ficamos só no posto de vigilância, lá em baixo, para ninguém entrar e eles ficarem lá um ano, cinco anos, dez anos, cem anos ou mil anos? Por que que nós temos de ir lá? A terra foi demarcada para os índios.

Santilli: Eu não estou dizendo que você tem de ir lá. Estou dizendo que há situações em que, se O Estado brasileiro não vai, outros estarão lá.

Possuelo: Mas que outros, o quê vão fazer lá? Quem vai lá? Fazer o quê?

Santilli: O garimpeiro, vai... qualquer filho da puta... eu quero te dizer... eu imagino que na tua vida... eu estou querendo arrancar uma coisa de você,

${ }^{11}$ Cooperativa Agrícola de Ijuí. 


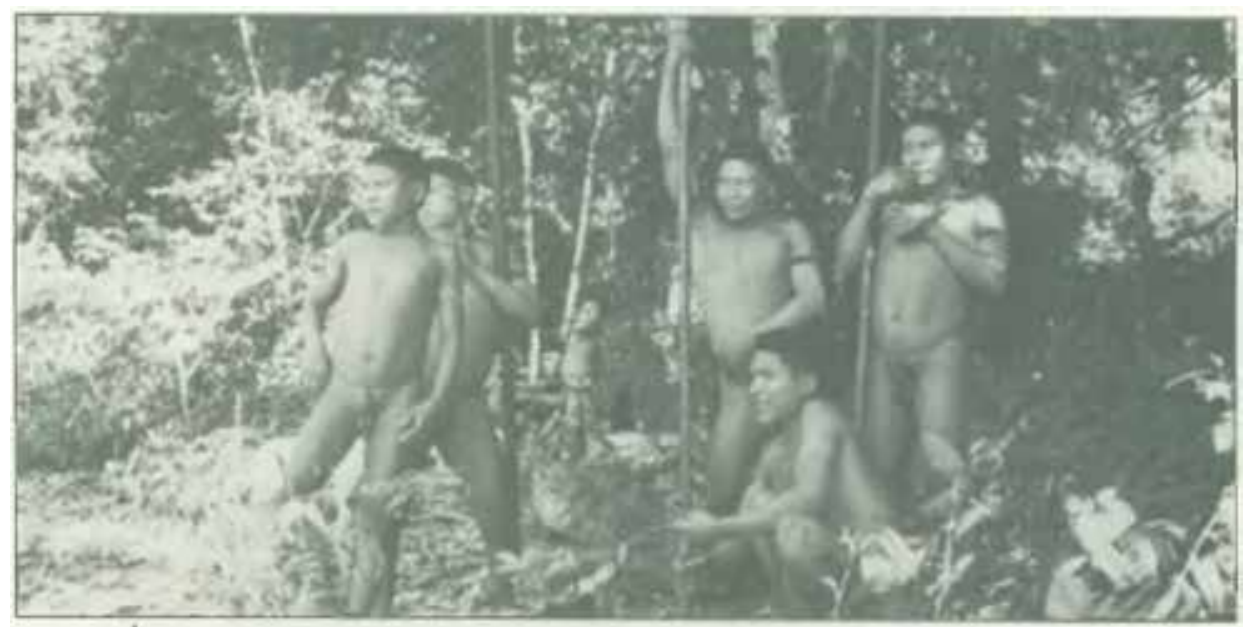

Índios Korubo do Vale do Javari, armados de zarabatanas. Da esquerda para a direita, Wiramar, Xixum, Tenhú, Tsamabó (de pé, em primeiro plano), e Tak'pa (abaixado). Foto: Divulgação do Departamento de Índios Isolados da Funai.

entendeu? Eu imagino que na tua vida, você deve ter tido momentos em que teve de dizer:

- Eu tenho de fazer a violência menor para não rolar a maior!

Essa é uma decisão radical!

Possuelo: Se você quer uma coisa dessa, eu vou te dar um exemplo concreto disso que você está falando...

Elias: Os Korubo, por exemplo, agora que vocês...

Possuelo: O caso dos Korubo, pronto!

Elias: Eu gostaria de ver, nessa sua perspectiva, o caso de Rondônia em que nós temos essa situação de um índio. Mas nós temos o Vale, ${ }^{12}$ em que os índios tinham confronto com os madeireiros. É uma situação em que vocês definiram até hoje não fazer contato. A terra tem um projeto de demarcação, sem que esses indios tenham contato regular com a sociedade regional. E a tua decisão de fazer contato com os Korubo, no Amazonas. São três situações, né? Temos o indio sozinho, temos o Vale, que tem uma população, que o processo de identificação é muito particular, e Korubo, que vocês decidiram, então, fazer contato.

Possuelo: Eu acho que o melhor exemplo está nos Korubo e, para entender a situação dos Korubo, a melhor coisa que você tem a fazer é um desenho assim [desenha um mapa]. Esses aqui são os dois rios principais de onde sai a maior parte de madeira dojavari. ${ }^{13}$ Esse aqui é o Ituí e esse aí é o Itaquaí. Aqui é a

\footnotetext{
${ }^{12}$ Vale do Guaporé, no estado de Rondônia.

${ }^{13}$ Vale do Javari, no estado do Amazonas.
} 
confluência deles. A terra indígena começa dessa confluência para dentro, para cá. Aqui entra madeireiro - entrava! Não entra mais, há três anos, acabou! Não entra mais madereiro, pescador, não entra ninguém, ninguém entra mais, certo? Nós montamos um posto de vigilância aqui.... o centro real dos Korubo é nesse rio aqui, chama-se Branco. Nunca fizemos contato com eles, não tem necessidade. Aqui tem esse grupo. Mais para cá, tem outro grupo chamado Flecheiro. Aqui tem um igarapé, faz isso o igarapé.... Aqui não é terra indígena, essa parte aqui. Aqui tem pequenos povoados de brancos. Aqui e aqui, houve ataques sobre esses índios, que nós não sabíamos que índios eram. Quem são eles, essas pessoas aqui? Descobrimos, então, uma maloca aqui. Dessa maloca para essa confluência aqui, onde tínhamos que fincar nossa base, dá exatamente $17 \mathrm{~km}$ em linha reta. A última morte deles, seis meses antes de nós chegarmos, foi exatamente aqui, num lugar chamado Ladário. Eu falei para o pessoal:

- Quando nós colocarmos o nosso ponto de vigilância aqui, esse pessoal vai vir nos atacar. Eles atacam todo mundo! Eles matam os caras aqui, por que é que não vão nos matar? Nós não temos estrelas na cabeça. Eles vão nos matar.

Agora, onde é que eles estão? Aí, fiz três expedições nessa área e descobri aqui a aldeia deles. Disse:

- Antes que eles venham aqui nos atacar, eu vou lá ver se consigo conversar com eles, levando intérprete; vamos ver se a gente apresenta para eles a nossa proposta. Nós vamos ficar lá morando, naquele ponto etc. etc. Vamos fazer uma aproximação com eles. Vamos ver se vai dar certo.

Um dos índios que estava conosco, que é o Matis, conseguiu falar com eles. Nós ficamos exatamente três dias a $1.500 \mathrm{~m}$ de distância da aldeia, eles nos visitando. Nós dissemos que estávamos morando aqui nesse barco. Tinha um barco aqui. Esse barco não era para descer, mas mais tarde... Eles começaram, passaram a nos visitar aqui, a visitar esse barco, vinham na beira do rio: - Oi, oi...

A gente descia, falava com eles, com muito cuidado. Eles também, claro! Eles de nós e nós deles, com um medo terrível!

Mas, numa das minhas saídas, vim embora para cá, o barco desceu - e eles acompanham

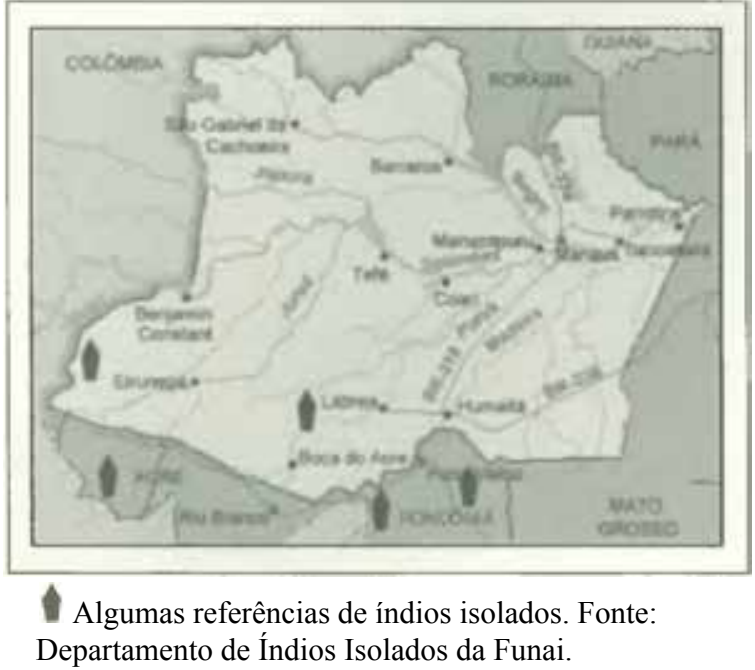

Departamento de Índios Isolados da Funai. 
o barco - e ficou logo aqui, a 1.500m de onde houve aquele massacre em cima dos Korubo, chamado de Korubo, que é esse grupo que está aqui. Vieram para cá, houve a morte, houve o ataque em cima do nosso amigo lá, foi uma coisa terrível aquilo, que culminou com a morte do Sobral. Depois disso, voltaram, estão lá. Eles vão para a floresta, ficam lá. Nós nunca fizemos esforço, nunca fizemos nada, nada. Eles moram na casa deles, têm a sua vida tradicional. Acontece que passaram a vir também nesse lugar, chamado Ladário, onde um dos antigos matadores de índio também mora. Mora lá! Morava dentro da terra indígena e eu botei ele para fora. Disse-lhe:

— Você não pode morar aqui, você matou índio cara, vai embora.

Mas ele está no Ladário. Os índios Vão la ainda. Esse e um dos grandes medos nossos, uma hora vai dar um conflito. Uma hora, ou eles vão perder a cabeça com os índios ou os índios vão perder a cabeça com eles.

Então, no Vale do Javari - que, na verdade, tem cinco grupos isolados, fora esse que já mantém um contato conosco e que não consideramos mais isolados, estamos numa fase de muitos cuidados; temos de ter cuidado, mas isolados eles não são mais não, porque já fomos lá, já falamos, já trocamos objetos, dormimos com eles, entraram dentro de nosso barco; já houve troca; então não é mais grupo isolado - é só isso. Nosso trabalho lá é um trabalho de evitar invasões. Nada mais. Nada mais no Vale do Javari. O que já é extremamente complexo porque nós somos perseguidos pelo governador, pelo prefeito, pelos políticos; todos falam mal de nós, pedem a nossa cabeça, ameaçam-nos de morte - como ameaçaram a nossa equipe lá, a mim pessoalmente, e tudo o mais. Para o Acre seria a mesma coisa. A nossa proposta para o Acre é a mesma.

Edward: Só de curiosidade. Quando é que esse grupo aqui estaria apto para receber a visita de um antropólogo, por exemplo?

Possuelo: Olha, eu não penso nisso não. Eu não acho que antropólogo deva ir lá. Fazer o quê? Trazer conhecimento para o nosso deleite? Dizer:

— Eles têm artesanato? Têm primo cruzado?

Isso não traz nada para o índio. Ele tem de viver a sua vida.

Marco Paulo: A justificativa dada para o contato com os Korubo foi a necessidade de avisá-los que vocês estariam ali para protegê-los...

Possuelo: É! Pena que eles não entenderam até hoje direito, isso aí... [risos]

Marco Paulo: Apesar disso morreu uma pessoa na frente de contato...

Possuelo: Morreu, morreu...

Marco Paulo: E parece que eles continuam mantendo contato com a população de Ladário. Eu queria saber o seguinte: qual o tipo de trabalho que a frente 


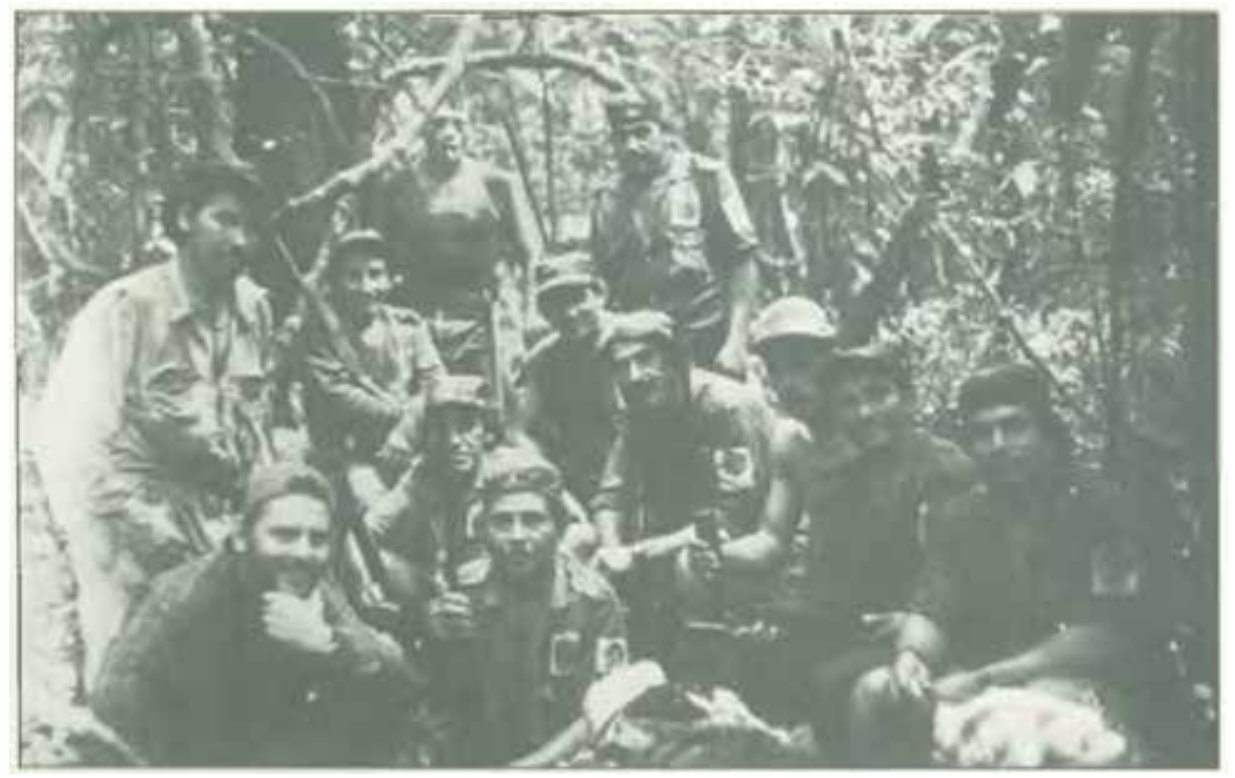

Frente de Contato do Vale do Javari. Atrás de Possuelo, ao centro, Raimundo Batista Magalhães, o "Sobral", indigenista morto pelos Korubo, em 1997; com uma espingarda na mão, agachado à frente, Afonso Alves.

desenvolveu junto à população de Ladário? Ou seja, eu entendo também que um dos objetivos principais de uma frente de contato não é o trabalho com os indios. E você acabou de confirmar com sua fala, dizendo que o objetivo não é esse. Então, fica subentendido que o principal objetivo de urna frente de contato é trabalhar a população do entorno. Então eu pergunto: o que foi feito, o que a frente tem realizado..., qual o trabalho desenvolvido com a população de Ladário?

Possuelo: Afora as rápidas visitas que fizemos ao Ladário, conversando com o pessoal, na nossa chegada, tudo estava bem, com Ladário e com os outros povoados. Porque eles pensavam que conosco seria da mesma forma do que com as equipes anteriores. Foi criada há muitos anos, antes de nós chegarmos, uma equipe que colocou exatamente aqui nesse campo, que era equipe para não deixar ninguém entrar. Essa equipe estava lá antes. $\mathrm{O}$ pessoal da região, que subia e passava, quando chamávamos para que parassem, ninguém parava. Diziam:

— Seu bando de come e dorme!; Vai à merda!; Que pára coisa nenhuma!

Mas era assim, palavra de baixo calão mesmo, entende? E o pessoal entrava, não fazia nenhum controle, era para controlar quem entrou, quem não entrou etc. Quando nós chegamos, montamos a equipe, e decidimos:

— Não vai subir ninguém, mesmo!

E eu trouxe um pessoal que não era da região. Então não tinha primo, não tinha 
parente... que lá nessa região é sempre assim: o cara da Funai sobe num barco, tem primo, tem parente, tem conhecido, tem gente que depende uma da outra. Esse pessoal que vem comigo, não. É independente. E aí começamos:

— Não, não e não.

Uma nova situação de fato. Então, quando começou essa situação de fato, de nossa negativa, a possibilidade de nós descermos e conversamos com o pessoal da região foi ficando cada vez mais difícil.

Para você ter uma idéia, o menino que está respondendo agora pela frente, ${ }^{14}$ há pouco tempo - foi no ano passado - ele, para sair da cidade de Atalaia, uma multidão veio em cima para pegá-lo. Ele era o chefe da frente. Ele teve de sacar a arma e dar dois tiros para cima e abriu à bala o caminho, saiu correndo, entrou dentro do barco, ligou o motor e foi embora. Ele não pode mais descer lá. E quando desce lá o nosso pessoal, desce em três, quatro, cinco... E todo mundo armado mesmo, porque, se não, arrebentam, matam, botam para correr, isso só para você ter uma idéia.

Mas, independente disso, e sabendo de nossa impossibilidade de estarmos ali mais presentes, nós fizemos um plano, um projeto, que está na Comunidade Européia há três anos. Agora, recebi informação deles dizendo que foi todo aprovado, está com as assinaturas e que até o mês de março sairia do papel. Entre várias coisas, ele abarca exatamente esse tipo de estudo, dos ribeirinhos, para promover a convivência pacífica, promover alternativas econômicas para os ribeirinhos... ajudá-los em alguma coisa! Para os índios também, para os grupos contatados... É muito amplo. Porque a Funai não faria nada. A Funai não faz para os índios, vai fazer para os brancos?

Edward: Mas os índios não são isolados? O objetivo não é ficar isolado? Então por quê...

Possuelo: Porque dentro da área do Vale do Javari tem outros grupos que não são isolados. O nosso projeto abarca esses grupos... Contempla.

Santilli: Eles puxaram uma reunião com os ribeirinhos, uma iniciativa deles de estabelecer ali úma relação mínima e tal com...

Possuelo: Como?

Santilli: Os Varja, aquele pessoal, puxou uma reunião, chamou os ribeirinhos...

Possuelo: É... Que é sempre problemático, também. As lideranças regionais são extremamente problemáticas, entende?

Santilli: Vende madeira de outros...

Possuelo: É. Então você precisa trabalhar essa coisa. E para trabalhar isso tinha

${ }^{14}$ Valdes Marinho Lima. 
de ter um projeto que contemplasse a necessidade de sobrevivência dos grupos já contatados, que querem fazer negócio etc. etc., com a intocabilidade de áreas que, dentro desse territórios, ficassem intocadas só para os isolados poderem viver e sobreviver ali, sem maiores...

Elias: Eu gostaria que você caracterizasse as frentes, as diferenças entre a da Reserva Biológica do Guaporé, em Rondônia, e a de Lábrea, no rio Purus você já falou um pouco lá do Envira, no Acre -, considerando que todos esse lugares foram frentes economicas de desenvolvimento. Então, a Funai tinha uma perspectiva que você diz que vocês implantaram. Como se dá o financiamento dessas frentes, as equipes, essa atuação, que o Marco tinha lembrado, com o entomo etc.? Acho que elas têm sempre características próprias.

Possuelo: Por sinal, foi muito bom você ter falado isso, principalmente porque me lembrou da reserva do Guaporé. A reserva do Guaporé - que está sendo demarcada agora, a demarcação está sendo concluída — é a primeira reserva indígena que nós estamos demarcando sem saber a etnia que está lá dentro. Foi um trabalho do nosso Departamento de não manter contato, monitorando, verificando. Mas o custo disso é muito mais alto do que se você vai, faz contato, delimita, um ano ou dois anos depois já tem gente que sabe a língua, e você já fala logo com os índios e eles dizem logo os seus limites. Numa frente assim, você tem de sair com as equipes e ver até onde você acha vestígios ao norte, ao sul, a leste, a oeste... e começar a traçar aquele universo deles ali. Então, esse trabalho foi um trabalho do Marcelo, a equipe nossa lá, que é a equipe do Marcelo, durante anos, inúmeras equipes entraram e faziam as expedições lá dentro. Por várias vezes abalroavam os índios e voltavam correndo para não fazer contato. Entende? Ou melhor, eu tenho três relatórios; três vezes a equipe viu os índios e voltou. E que é o resultado dessa política implantada desde a época que nós fizemos o Departamento. Era isso que a gente queria fazer ali e estender para o Acre, estender para as outras áreas.

Agora, o Guaporé é uma questão também sui generis. Por quê? Porque o Guaporé só tem grupos de índios isolados, então fica fácil você chegar e falar:

— Bom, está mais ou menos dimensionado.

Está perfeito? Não, não está perfeito. Mas até onde eles vão, nós temos aquilo monitorado e sabemos que se houver um errinho pra cá, um errinho pra lá... mas compensa você não fazer o contato, deixá-los e demarcar aquela terra. É o que está sendo feito. No Acre não é mais possível fazer isso. No Acre tem outras etnias...

Marco Paulo: Sobre essa demarcação sem contato, que é uma coisa muito interessante, do ponto de vista fundiário e do ponto de vista técnico também, eu tenho duas perguntas. Qual é a metodologia que está sendo usada parafazer essa demarcação... 
Possuelo: A mesma...

Marco Paulo: A pergunta é a seguinte: como se está definindo o território? E a outra pergunta é a seguinte: tendo em vista aquela velha cantilena, da soberania nacional, sobre a questão de "muita terra para pouco indio " etc. - isso ainda é visto como bode expiatório, essa questão da terra indígena - quais seriam os antídotos, vamos dizer assim, inclusive para esse tipo de discurso, para esse tipo de argumento político, para a demarcação de terras de indios isolados, ou seja, de índios não contatados? Quem é também um...

Possuelo: Como eu dizia, é mais ou menos o seguinte: é muito mais difícil, mais trabalhoso e portanto é mais caro você fazer esse tipo de trabalho. Porque você demora mais tempo nas expedições, aí vêm os índios, aí volta, "não dá para fazer expedição agora que eles estão aqui, vamos ver se dá para checar a outra área..." Então foram pelo menos, que eu me recordo, de trabalho do Marcelo indo lá, foram sete anos de trabalho. Que eu me recordo. Sete anos para ele montar aquele universo de ocupação. Certo? Sete anos! Depois de montados, aí eu tinha já alguma coisa a oferecer, aí eu pedi a demarcação. E aí começou a entrar no processo normal: é criado um grupo, um antropólogo vai, se une à nossa equipe, lá, percorre, vê... Teve um facilitador na área noroeste, porque ali era uma reserva ecológica, toda essa área era uma reserva do Ibama. Mas a nossa idéia era sempre a seguinte: o índio precede a questão de reserva ou não reserva. Primeiro vamos atender às populações indígenas. Depois, as demais questões. Mas a nossa proposta é um trabalho em conjunto, porque nós fazemos limites, fronteira com eles, com o Ibama, entende? Então, está previsto o Ibama botar dois postos lá etc. etc. Mas na verdade você só tem a Funai funcionando lá. Mal e porcamente, porque os rapazes estão sem nada.

Elias: Era uma reserva...

Santilli: REBIO - Reserva Biológica.

Elias: Invadida por madeireiros. No início da década de 90, teve aquela exposição promovida pelo Bené Fonteles, "Armadilhas indigenas". Foi o Antenor ${ }^{15}$ quem mandou os estrepes para o Bené. ${ }^{16}$

Possuelo: Isso...

Elias: Esses índios tinham contato ou confronto com madeireiros.

Possuelo: Ah, tinham! Olha, eu não creio que haja nenhum grupo indígena isolado no Brasil que não saiba de nossa existência, entende? Todos sabem! Porque, em algum momento da história deles, eles tiveram encontros fortuitos

\footnotetext{
${ }^{15}$ Antenor Vaz, responsável pelo trabalho no Vale do Guaporé.

${ }^{16}$ Como estratégia para impedir a entrada dos madeireiros, caçadores etc. em suas terras, os índios preparavam armadilhas colocando nos caminhos estrepes, alguns deles envenenados.
} 
ou choques com essas frentes pioneiras, por aí a fora. Mas nós estávamos falando de um modo geral das frentes, né?

Elias: É. Tem uma situação muito particular, que é um grupo pequeno, a falta de condições ali, mas tem também o problema do reconhecimento da população regional e dos poderes local e federal, porque, além dessa questão de ter ou não índios isolados, tem a dificuldade de se aceitar que há um novo grupo indígena no estado, porque isso vai tirar terras para projetos, e tal...

Possuelo: De um modo geral, o que a gente pode dizer com a ação governamental, seja governo federal, seja estadual ou municipal, aqueles que estão mais próximos dos índios - eu tenho visto, eu tenho sentido isso na minha vida — são os que mais são contra os índios, são os mais contrários aos interesses indígenas. Porque eles têm os seus interesses partidários, eles dizem defender os ribeirinhos, que são infelizes, isso e aquilo, aquilo mais etc. etc. Só para dar um exemplo: nessa região em que houve o massacre no Vale do Javari, tem dois massacres - isso eu estive na Polícia Federal conversando com eles - em que os políticos regionais compraram a munição e distribuíram para os ribeirinhos se vingarem, porque estavam todos eles emocionados, que morreu alguém etc. etc. Tá entendendo? Então, o que eu quero dizer com isso é o seguinte: é que os governos mais próximos aos índios - municipal, estadual, depois, um pouco mais distante, o federal — são os que menos querem saber de problema indígena, os que menos atuam em favor dos índios, com raríssimas exceções. Nós temos algum exemplo tão gratificante, que é até bom a gente falar, como foi o caso desse nosso governador do Amapá, ${ }^{17}$ que tem se interessado muito, que tem atuado e todas as informações que eu recebo de lá... eu nem sei de que partido ele é!

\section{Memélia: Do PSB, Partido Socialista Brasileiro.}

Possuelo: PSB, né? Então, você tem esses isolados, esses políticos isolados [risos] — como o governador de lá — , que são pessoas já mais sensíveis etc. Mas de um modo geral, o que a gente pode dizer é que, quanto mais próximo do índio, menos o defendem. Muitas vezes foram eles promotores — até alguns anos passados, há não muito tempo - promotores de chacinas, promotores de represálias contra os índios. A nossa história está cheia disso, não é? E eu não digo no tempo do SPI, não! Eu digo depois do SPI, já em tempos modernos, atuais, agora com a Funai. Você vê Roraima, você vê... essas áreas distantes, o Acre... Você entra ali, você entrou no início do século, praticamente. A mentalidade é sempre aquela mesma. Tem esse estereótipo sobre os índios:

— É tudo um bando de vagabundos, e não faz nada etc.

Eles não concebem outro tipo de vida, diferente, né? O cara tem de se matar

${ }^{17}$ João Capiberibe. 
como nós, ganhar câncer... E morre civilizadamente, com câncer.

Victor: Você participou, por exemplo, da frente de atração dos Arara, em uma época em que essa posição que você acaba de defender e expor ainda não era a sua, ou pelo menos a da Funai, e foi antes da criação desse Departamento. $O$ que aconteceu com os Arara, passados alguns anos?

Possuelo: Eu fui para lá, sabe por quê? Em 1979, foi o maior ataque que os Arara tinham feito contra a Funai. E foi quando flecharam o Afonso Alves ${ }^{18} \mathrm{e}$ mais outros dois companheiros. Isso foi no final de 79. No início de 80 eu fui para lá. O presidente da Funai me chamou e disse:

— Sydney, a frente está lá há nove anos...

Nove anos já tinha a frente. Durante os nove anos, tínhamos sofrido três ataques razoavelmente fortes e uma dezena de incidentes nas fazendolas, que estabeleciam, ali, confrontos... Os Arara saíam ali, naquelas vicinais todas, e atacavam. Do pessoal da Transamazônica que entrou, do pessoal da CPRM ${ }^{19}$ que pesquisava exatamente nessa época, três foram mortos. Nossa equipe teve de ir lá resgatá-los, porque as três pessoas que formavam a equipe da CPRM, um desmaiou e os outros dois tiveram problemas sérios... Então eu tinha ido naquele momento.

E o Ismarth ${ }^{20}$ - que hoje nós vemos, com todo o militarismo, o Ismarth foi um ótimo presidente da Funai, principalmente naquelas condições de militar, mas também tinha mais dinheiro naquela época, né? — falou:

— Você vai e me diz o que precisa fazer.

Eu respondi:

— Tá bom.

Fui e fiquei uma semana lá, sobrevoei a área, voltei apresentei meu relatório:

- É isso que precisa fazer.

E eu queria voltar para onde eu estava. Ele falou:

— Não! É esse o teu plano? Agora você vai lá e aplica.

Eu retruquei:

— Bom, é sacanagem! Você não tinha combinado isso comigo.

Eu não queria ir. Bom, mas aí eu fui para lá.

Tem a área dos Arara, tradicional, ocupada por eles. A Transamazônica passava

\footnotetext{
${ }^{18}$ Indigenista da Funai, na foto da página 182.(na versão original, página $\mathrm{X}$ deste volume)

${ }^{19}$ Companhia de Pesquisas de Recursos Minerais, órgão do Ministério das Minas e Energia.

${ }^{20}$ Coronel Ismarth de Araújo Oliveira, presidente da Funai entre 1974 e 1979.
} 
por aqui [desenhando outro mapa]. Aqui também era área deles, tinha um grupo aqui. Ninguém sabia que tinha esse grupo. Aí nós chegamos, fizemos um posto. A frente foi seguir os índios, ir atrás dos índios, querendo fazer contato, contato, contato, contato... Porque os administradores, delegados regionais, ficavam lá para o pobre do meu amigo:

- Você tem de ir, tem de fazer contato, seu lugar é na selva. Vai lá atrás deles... E ele saía e tomava flechada na bunda o tempo inteiro. Então, eu fui e vi que perseguiam demais índios.

— Índio precisa de tranquilidade, vamos nos estabelecer aqui, disse.

Depois de um mês, um mês e pouco que nós nos estabelecemos, fiz um fortezinho - o "Forte Apache". Quatro meses depois, fomos atacados. Nós vivíamos permanentemente rondados por eles. Não podia se sair à noite, nada. Eles estavam em volta o tempo inteiro. Com quatro meses nos atacaram. Eu permaneci com a mesma disposição, aumentei o brinde lá no tapiri, fiz as mesmas coisas... Com cinco meses, eles mandaram o Aktô entrar - aquele menino, o Aktô, que tinha nove anos, hoje está um "homão", já tem filho. E a gente manteve o primeiro contato. Com nove meses, fizemos o contato, o primeiro contato. Era só uma questão de dar um pouco de paz, sossego para eles. Eles estavam muito perseguidos pela frente, que ficava fustigando eles; pelos fazendeiros, das vicinais, que se estabeleciam lá; os caçadores - o pessoal daquelas fazendas, todo final de semana, vai brincar, vai caçar, né?

Então, foi só isso. Para tirar aquilo ali. Depois eu descobri o grupo do lado de cá, fiz o contato com eles. Não fiz transferência. Foram eles que quiseram vir. Veio para mim dos Estados Unidos um filme dos Arara. Aí o cara que faz o filme diz:

— E aí, os que fizeram contato, transferiram...

Eu não transferi ninguém para lá. Eles que quiseram vir atrás, o pessoal de lá. Mas enfim... Tinha esse grupo e depois nós descobrimos um outro grupo, que foi o grupo que mais tempo demorou, que foi aquele grupo barbudo. Um grupo... todos eles têm uma barba cerrada igual à nossa, cerradona. Demorou oito anos para fazer o primeiro contato.

\section{Santilli: Eram Arara?}

Possuelo: Eram. São três grupos Arara. Então, esse último grupo, nós demoramos oito anos para contatar. Eu fiz muita expedição na área, porque estava muito invadida, a gente precisava conhecer, uma área cheia de pico, difícil andar ali. E quando nós entramos, por onde a gente passava, nossos acampamentos eram destruídos. Quando voltava - em algumas oportunidades eu voltei pela mesma picada que eu tinha aberto- nós encontrávamos tudo destruído. Aí foi que nós descobrimos que tinha um grupo que estava atrás de nós, destruindo nosso 
acampamento. Falei:

— Este grupo tá querendo nos pegar.

E, realmente. Demoraram oito anos. Com oito anos eles chegaram no posto do Iriri, que é o Cachoeira Seca. Chegaram e deram o primeiro contato conosco. Demoraram oito anos.

Memélia: Eu me pergunto aqui como é que era a população envolvente, que trabalho foi feito com a população envolvente. Dia 12 de outubro de 82, quando eles chegaram em Altamira, houve aquele encontro que foi realmente inesquecivel.

Possuelo: Foi fantástico! Pena não ter filmado. Eu tenho dois arrependimentos: não ter filmado aquilo ali e terem roubado do Museu do índio os filmes, que eu mandei aquela equipe realizar. Quando os Arara adoeceram, mandei filmar. Então, pela primeira vez você tinha nosso trabalho no meio dos índios doentes. Eu queria mostrar:

- Olha o que acontece! Essa porra acontece!

Coisa horrível! Caminhando na selva, trazendo índio nas costas, para dar os remédios, né?

Memélia: Conta a reação dos Arara, quando eles descobriram a buzina daquele jipinho...

Possuelo: Ah! Nós tínhamos um Toyota, e o Toyota entrava e parava no pátio. E, eles estavam em seus primeiros momentos conosco: chegavam e olhavam as coisas, e eles abriram o teto, foram nas caixas onde a gente tinha os brindes e roubaram tudo, tudo. E o meu pessoal fechava aquilo e eu falava:

- Negativo. Abre tudo. Deixa levarem tudo.

E levaram tudo. E eles começaram a olhar o carro. Eles já conheciam carro eles sempre viam carro pela Transamazônica, eles vêem carro, caminhão, mas nunca tocaram carro. Aí eles chegaram perto do carro e começaram... Chegaram, começaram a botar a mão na lataria, a tocar, conseguiram abrir a porta. Abriu a porta, um entrou, um jovem entrou. E mexe, e bota a mão devagar- ele bota assim, devagar mesmo, olhando, né? De repente ele toca na buzina: Piiii! Os índios que estavam em volta correram todos, o que estava lá dentro levou aquele susto! Depois, foram voltando devagar, em volta do carro outra vez. O outro foi com a mão na buzina, o que ficou dentro: Pii!, Pii! Olha! Dez minutos depois, o que estava dentro fazia assim: Pi... Pi... Pi... E o resto dançando em volta do jipe. Com arco, com flecha. Fantástico! [risos]

Agora, a história mais fantástica com esse grupo foi o seguinte: a 200m do posto, quando começava a orla da mata, fizemos um tapiri onde eu punha os brindes para eles. Eu botava lá faca, facão, machado, panela, essas coisas. Mas eu só 
punha quando eles também punham coisas deles. Era troca. Então, chegava lá tinha um facão feito de bambu que eles cortavam, imitando o facão. É para pedir o facão... Então eu tirava aquele e botava um facão. E aí eles deixavam mel, um pedaço de caça, um diadema. Deixavam ali. E a gente sempre fazia isso. Era um dia assim que o sol estava tarde, debaixo da mata fica meio escuro. Então eu levei a lanterna para eu ver melhor, né? Bom, vamos lá com as coisas e eu cheguei no tapiri, e ele tem um jirau - jirau é como se fosse uma mesinha. E eu peguei a lanterna e botei em cima. Uma meia hora depois fomos embora, voltamos. E ficou a minha lanterna. Lá dentro eu falei:

- A minha lanterna, esqueci minha lanterna lá. Bom, amanhã a gente pega. Claro, chegou no dia de amanhã, mas tudo o que ficava naquela mesa os índios já sabiam que era deles, nós tínhamos deixado para eles. Então, no dia seguinte cadê a lanterna? Foi embora.

Bom, passaram-se quatro anos para eu saber o que aconteceu com aquela lanterna, por uma mulher chamada Coré-Coré, esposa de Totí. Sem nada, um dia ela começou a contar. Dando risada, ela dava risada. Contou o seguinte: eles foram, pegaram as coisas e viram aquela coisa que eles não sabiam o que era direito:

— Mas já que deixaram aqui é pra nós, vamos levar.

Levaram, andaram, andaram..., lá pra dentro da mata. Chegaram no acampamento deles. Fizeram um foguinho, assando lá o macaquinho, a comidinha deles, de noite. E um dos homens, agachados, um rapaz, com a lanterna na mão, e olha a lanterna e mexe na lanterna... e a lanterna acende. Quando ela acende, ele dá um pulo, joga a lanterna e grita o seguinte:

— Tá vivo! [risos]

E todo mundo se afasta da fogueira, tá vivo, tá vivo, o quê que você faz?

- Mata! Vamos matar.

Então, um pega um pau, outro pega um facão e começam a bater. Até que, quebrou o vidro, mataram.

— Tá morto!

Um deles vai com o facão e joga o que sobrou da lanterna dentro do fogo. E voltam a sentar em tomo da fogueira. Alguns minutos depois, o fogo esquenta, a pilha explode, estoura, e joga cinza. E quando aquele negócio fez “puff!", eles gritaram:

— Tá vivo! Não morreu! [risos]

Desarmaram acampamento e foram armar noutro lugar.

— Tá vivo e ninguém mata isso. 
Agora, você tem que ver Coré-Coré contando isso, é uma coisa fantástica!

Santilli: Eu queria te perguntar sobre essa de sertanista. Porque, salvo engano, é uma espécie em extinção. Como é que você vê isso? Tem lugar para essa figura no futuro do Brasil?

Possuelo: Eu acho que é uma das poucas profissões que teve seu tempo exato, naõ é? O tempo exato de um sertanista é enquanto tem sertão. Acabou o sertão, acaba o sertanista junto com o sertão. As florestas estão acabando, então o que você quer mais... você não tem mais, como era antigamente... O sertanista, ele não é um expert. Sertanista quer dizer muita coisa e não quer dizer nada, na verdade. Sertanista deriva de sertão, e o que é um sertanista? É um cara que anda na floresta, que conhece um pouco a floresta, pressupõe-se que conhece índios etc. Que começou no tempo dos grandes e velhos e antigos sertanistas paulistas, que foram homens extremamente importantes no alargamento e na conquista do território nacional, com suas grandes entradas, bandeiras... Mas eles também eram um flagelo sobre os índios, eles eram matadores de índios. Matavam, destruíam, preavam os índios, traziam... Só mais tarde, através da figura de Rondon, é que começa a mudar o sertanista, né? De vilão, começa a ter uma conotação de homem que estava junto com os índios, que os defendia. Então, eu acho que só tem validade o sertanista quando ele tem um ambiente de trabalho: a própria selva... Nós estamos destruindo a selva! Para quê mais sertanista? Para quê mais macaco, para quê mais anta? Para quê mais... os bichos? Os bichos também estão desaparecendo. Então nós desaparecemos junto com os bichos e com a floresta. Então, morreu exatamente no seu tempo que tinha que morrer. Entende? É lamentável. Quer dizer, eu não sei se é lamentável tanto assim, não. Eu não sei. Enfim, deverá ter outros, vão aparecer novos nesses próximos quinze, vinte anos, vão dar outro nome.

Santilli: Uma nova versão moderna?

Possuelo: Naõ sei. Você sabe que eu nunca pensei assim, uma visão moderna... Talvez... o quê é que você pensa como o sertanista moderno? Talvez algo tipo um Rambo, cheio de GPS, com um monte de anteninhas, descendo de páraquedas:

— Encontrei a aldeia aqui, e tal... ok, câmbio, desça, chega.

E já vem uma turma com alta tecnologia de anfíbios que voam sobre as árvores, descem sobre os rios, fazem aquelas coisas, e tal.

- Chegamos aqui, estabelecido o primeiro contato, ok, chama a ONU, vamos lá...

Aquelas coisas. Eu não sei, naõ sei como... mas eu nunca pensei. Muita gente pensou em uma nova escola... Antes, há alguns anos, se falava nas escolas que se prosseguiam... não há mais nada para prosseguir. 
Elias: Vocês vão poder ir para a selva com telefone celular..

Possuelo: Cara, eu não sei nem se selva mais vai ter. Selva como a gente entendeu. Aquela selva perdida, distante. Hoje está tudo muito mais facilitado. Muito mais facilitado. A tendência é essa, facilitar. Mas eu acho que o novo não tem que, necessariamente, destruir o que é antigo. Os povos indígenas são antigos, são mais velhos. Não têm nada a ver com globalização ou qualquer outra coisa que de nossa cabeça achamos tem de ser assim sobre eles. Tem de ser assim para nós, que julgamos que tem de ser assim. Mas não submeter os índios a isso que julgamos. Isso faz parte da nossa globalização, é a tendência natural, não sei o quê... Eu ainda luto contra essa coisa. Claro que eu acho que vou ser levado de roldão, na avalanche. Mas eu prefiro ser levado de roldão do que fazer coisas que, no meu íntimo, não aprovo. Eu acho que não é legal. Para eles. 